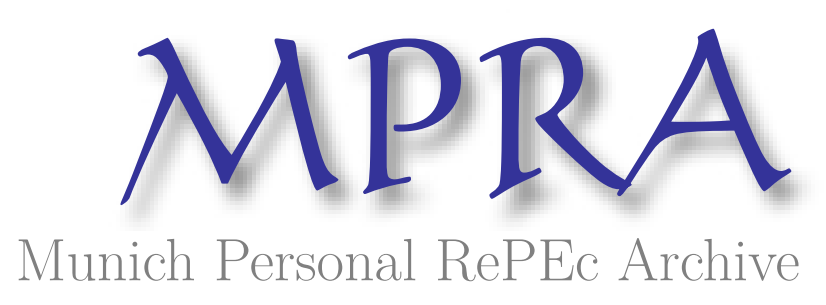

\title{
Predictive Models for Disaggregate Stock Market Volatility
}

Chong, Terence Tai Leung and Lin, Shiyu

The Chinese University of Hong Kong, Nanjing University

8 November 2015

Online at https://mpra.ub.uni-muenchen.de/68460/

MPRA Paper No. 68460, posted 21 Dec 2015 07:25 UTC 


\title{
Predictive Models for Disaggregate Stock Market Volatility
}

\author{
Terence Tai-Leung $\mathrm{CHONG}^{1}$ \\ Department of Economics, The Chinese University of Hong Kong \\ and \\ Department of International Economics and Trade, Nanjing University \\ and \\ Shiyu LIN, \\ Department of Economics, The Chinese University of Hong Kong
}

$8 / 11 / 2015$

\begin{abstract}
This paper incorporates the macroeconomic determinants into the forecasting model of industry-level stock return volatility in order to detect whether different macroeconomic factors can forecast the volatility of various industries. To explain different fluctuation characteristics among industries, we identified a set of macroeconomic determinants to examine their effects. The Clark and West (2007) test is employed to verify whether the new forecasting models, which vary among industries based on the in-sample results, can have better predictions than the two benchmark models. Our results show that default return and default yield have significant impacts on stock return volatility.
\end{abstract}

Keywords: Industry level stock return volatility; Out-of-sample forecast; Granger Causality.

\section{JEL classifications: $\mathrm{C} 12, \mathrm{G} 12$}

\footnotetext{
${ }^{1}$ We owe much to Liugang Sheng and Julan Du, and seminar participants at the Chinese University of Hong Kong for their helpful comments. We are also very much indebted to Min Chen, Margaret Loo, Yingshi Chen, Junjie Guo and Mandy Cheung, for their assistance in the research. Any remaining errors are ours. Corresponding author: Terence Tai-Leung Chong, Department of Economics, The Chinese University of Hong Kong, Shatin, N.T., Hong Kong. Email: chong2064@cuhk.edu.hk. Web page: http://www.cuhk.edu.hk/eco/staff/tlchong/tlchong3.htm.
} 


\section{Introduction}

The determinants of stock return volatility have long been studied over the past two decades (Campbell, Lettau, Malkiel and Xu, 2001; Sohn, 2009). Although these studies commonly look into a wide range of macroeconomic variables, their different methodologies yield results that are hardly comparable. While some studies suggest that macroeconomic factors have impacts on stock return volatility, others find such evidence lacking. Schwert (1989) examines the relationships between stock return volatility and economic activities using monthly data from 1857 to 1987 . He finds that inflation volatility predicts stock volatility for the period 1953-1987, money growth volatility is a good predictor of stock return volatility, and industrial production volatility weakly explains stock return volatility. Kearney and Daly (1998) show that conditional inflation volatilities and interest rates have direct impacts on Australian stock market volatility. Engle and Rangel (2008) also argue that volatility in macroeconomic factors, such as inflation, short-term interest rates and GDP growth, could explain the increase in stock market volatility.

In the literature, very few studies have examined the impact of macroeconomic variables on stock return volatility at the industry level (Faff and Brailsford, 1999; Hess, 2003). Figure 1 depicts the fluctuations of stock market volatility of the S\&P 500 value-weighted market portfolio and major industries from 1927 to 2012. The countercyclical characteristic of stock return volatility is largely consistent among these major industries. However, since 2000, the stock return volatility of the Hitec 1 (Business Equipment and Telecommunication) sector has increased, particularly during the dot-com bubble, the 9/11 terrorist attacks, and the 2008 financial crisis. In addition, the stock return volatility of Cnstr3 (Construction) is quite different from the 1930s to the 1950s. These facts demonstrate that the volatilities of stock return in 
different industries have different levels of sensitivity towards macroeconomic factors.

Industry analysis contains important information for asset allocation, which helps control portfolio risk by diversifying investments across various industries. The objective of this paper is to investigate whether different macroeconomic factors can forecast the volatility of various industries. A multi-factor augmented model is constructed by adopting the main approaches in Schwert (1989) with U.S. stock market data across different industries over the period 1927 to 2012. Paye (2012) concludes that the macroeconomic variables Granger cause stock return volatility at monthly horizons, and that the default return and default yield spread are the two variables contributing the most. Following Paye (2012), we include explanatory variables that reflect monetary policies (default return and default yield), economic conditions (industrial production growth and its volatility) and price levels (inflation rate).

The findings illustrate that for major industries, the aforementioned variables have significant impacts on stock return volatility. Meanwhile, differences in the impact of macroeconomic variables are evident among disaggregated industries. These new forecasting models are empirically superior, based on the results of the in-sample analysis. As for the out-of-sample analysis, the new forecasting models perform better than the benchmark models constructed by auto-regressions or basic settings for the aggregate market. However, the superiority is not exactly the same under the two approaches in four sub-periods. 
The remainder of this paper is organized as follows. Section 2 reviews the relevant literature on the differences in the fluctuations and macroeconomic determinants of stock return volatility at the industry level. Section 3 describes the variables and data. Sections 4 and 5 present the methodology and empirical results of in-sample and out-of-sample analyses respectively. Section 6 concludes the paper.

\section{Literature Review}

The attempt to examine the different effects of macroeconomic factors on volatility in different industries is mainly driven by the diverse characteristics of industry-level volatility. Some industries are cyclical, such as the oil and gas industry (Sadorsky, 2001) and durable equipment-based industries (machinery and transportation equipment). Conversely, non-cyclical industries, such as food and beverage, tobacco, and utilities (Campbell et al., 2001), sail through economic downturns. Boudoukh et al. (1994) conclude that stock returns in non-cyclical industries tend to co-vary positively with the expected inflation, while the reverse holds for cyclical industries. According to Hess (2003), firms in sensitive sectors underwent severe structural changes during the 1990s recession because of fierce international competition and technological progress. Insensitive sectors, however, did not face such significant challenges at the time.

Fama and French (1997) find substantial differences in factor sensitivities across U.S. industries. As shown by Faff and Brailsford (1999), oil price movements have varying effects on different industries. Specifically, while a significantly positive sensitivity is spotted in diversified resources and the oil and gas industries, a significantly negative sensitivity is observed in the transportation, paper and packaging industries. In addition, sensitivities appear to be long-term phenomena. 
Based on the investigation on the Pacific Stock Exchange (PSE) Technology 100 Index, the conditional volatilities of oil prices, the term premium, and the consumer price index all have significant impacts on the conditional volatilities of technology stock prices (Sadorsky, 2003).

A relatively large number of studies focus on the varying impacts of interest rates and other factors in various industries. For example, Sweeney and Warga (1986) perform regressions on the stock returns of 21 industry portfolios against the market and a series of simple changes of long-term interest rates. They found that from 1960 to 1979 , only stocks of electric utilities and those of the banking, finance and real estate industries are consistently sensitive to interest rates. Dinenis and Staikouras (1998) conclude that the effect of unanticipated changes in interest rates on nonfinancial institutions is also statistically significant, but is substantially less significant than the corresponding effect on financial institutions. Specifically, with three-factor index model regressions, Oertmann et al. (2000) estimate interest rate sensitivity by looking into various types of financial companies and industrial corporations. Generally, the industrial corporations' equity returns are positively affected by interest rate changes. Oertmann et al. (2000) conclude that the relationship commonly presumed negative between interest rate shifts and stock returns is largely facilitated by financial companies in the market. Czaja and Scholz (2007) use the term-structure model to examine the linkage between variables and summarise the negative effects of the slope of term structure or term spread on stock returns. The effects, nonetheless, vary among industries. For instance, the automobile and utilities industries, which depend on large initial capital investments and long-term financing, are more sensitive to the term spread. 
For variables reflecting price levels, the service sector tends to react more sensitively to inflation surprises than the capital-intensive industrial sector does (Hess, 2003). Specifically, the reaction of hotels to inflation shocks is more than two time as strong as any other sector, as hotels may involve highly leveraged firms. Retail-related sectors likewise are quite sensitive to inflation shocks, which may be attributable to consumer behaviour. Comparatively, banks are only moderately sensitive to inflation surprises.

\section{Variables and Data}

\subsection{Explanatory Variables}

Since countercyclical volatility may arise from investor uncertainty towards economic status and risk premiums, observable variables correlating to these channels are examined in the following analysis. This paper utilises the following macroeconomic factors, which are sampled monthly from January 1927 to December 2012.

\section{Industrial production growth (ipg)}

This variable is defined as $i p g_{t}=\ln \left(\frac{i p_{t}}{i p_{t-1}}\right)$, where $i p_{t}$, the U.S. Industrial Production Index, is sourced from the Board of Governors of the Federal Reserve System. It measures movements in the level of output and highlights the structural development of the economy.

\section{Volatility of industrial production growth (ipgvol)}

The volatility of industrial production growth is a proxy for the conditional 
volatility of growth in U.S. industrial production $\mathrm{ipg}_{t}$. We estimate an autoregressive model with 12-monthly dummy variables $D_{j t}$ to evaluate the monthly volatility of industrial production growth $\left(\hat{\varepsilon}_{t}^{2}\right.$, from the following regression). The volatility of industrial production is expressed as

$$
X_{t}=\sum_{j=1}^{12} \alpha_{j} D_{j t}+\sum_{i=1}^{12} \beta_{i} X_{t-i}+\varepsilon_{t},
$$

where $X_{t}$ denotes the monthly industrial production growth.

\section{Default return spread (dfr)}

This variable is the difference between returns from long-term corporate bonds and long-term government bonds. Data (including the following two variables, dfy and tms) are sourced from Goyal and Welch (2008), which was updated by Goyal through 2012.

\section{Default yield spread (dfy)}

This variable is the difference between the yield on BAA-rated corporate bonds and long-term U.S. government bonds.

\section{Term spread (tms)}

This variable is the difference between the long-term yield on government bonds and the Treasury bill rate.

\section{Factors representing price levels}

\section{Inflation rate (infl)}


This variable is defined as $i n f l_{t}=\ln \left(\frac{p p i_{t}}{p p i_{t-1}}\right)$, where $p p i_{t}$ is the producer price index of month $t$. The $p p i_{t}$ series is sourced from the U.S. Bureau of Labor Statistics website.

Industrial production growth and overall production growth provide useful information about the uncertainty towards macroeconomic prospects. The growth of the industrial production index can be consistent with the average growth of firms' sales and cash flows (Chen, Roll and Ross, 1986). Humpe and Macmillan (2009) find a positive correlation between the industrial production index and stock prices in both American and Japanese markets. In addition, stock market volatility may increase as industrial production volatility increases.

Paye (2012) argues that the most significant variables, in terms of Granger causality, from macroeconomic factors to stock return volatility are default return, default yield, and term spread. According to Chen et al. (1986), the default return has a zero mean in a risk-neutral world. It can be considered a direct measure of the level of risk aversion and implicit risk in the market's stock pricing, as well as a reflection of unanticipated movements in these risk levels. The default return reflects relative preference in the bond market based on corporate and government bonds returns. A higher default return indicates that corporate bond prices increase more compared to government bond prices. This represents a relatively greater demand for corporate bonds, which are riskier than government bonds. A higher default return corresponds to a lower level of risk aversion and hence, a lower risk premium. Under the assumption of countercyclical and asymmetric risk premium, prices and price-dividend ratios are not expected to increase significantly. Therefore, we 
anticipate stock return volatility to be negatively correlated with the default return.

The default yield spread responds aggressively at the onset of economic crises, when default probabilities of corporate debt increase dramatically. The default yield refers to the yield difference between BAA-rated corporate bonds and long-term U.S. government bonds, and can be treated as another proxy for risk premium that is calculated based on a company's quality. When the yield difference between BAA-rated corporate bonds and long-term U.S. government bonds is larger (i.e., the BAA-rated companies may have relatively larger default risk), economy-wide stress and subsequently a higher risk premium may result. Through the time-varying risk aversion channel, stock return volatility also becomes correspondingly higher. Chen et al. (1986) show evidence of a positive relationship between this default yield spread and stock returns.

Term spread, which is the difference between the long-term yield on government bonds and the Treasury bill rate, carries information about the changes in risk premium and monetary policy during crises (Fornari and Mele, 2013). Chen et al. (1986) suggest that this variable measures the unanticipated returns on long-term government bonds. The growth of term spread indicates that the long-term government bond yield increases more than the Treasury bill rate, and the demand for long-term government bonds increases. Through the risk premium channel, both the level of risk aversion and the amount of risk premium decrease. Therefore, the term spread should have a negative impact on stock return volatility.

Table 1 presents the descriptive statistics of macroeconomic variables over the period of 1927 to 2012. The Phillips and Perron unit root test is conducted for all variables. For the variables in Table 2, we have the $Z_{t}$ test statistics for the Phillips 
and Perron unit root test and calculated the associated Mackinnon approximate $p$-value respectively. Since the null hypothesis of a unit root test for all variables is rejected, we do not report the test results to conserve space.

\subsection{Stock Return Volatility}

This paper defines stock return volatility based on a classical definition of return volatility (i.e., realised volatility obtained through sums of observed squared returns within a reference period). This definition has been widely adopted (see, e.g., Anderson, Bollerslev and Diebold, 2007) since the pioneering work of Merton (1980).

In this paper, the aggregate stock returns for comparison are the S\&P 500 monthly returns (including all distributions) from a value-weighted market portfolio (i.e., CRSP_VWRETD sourced from the Centre for Research in Security Prices (CRSP)). The industry-level return comprises value-weighted returns from industry portfolios obtained from the Kenneth R. French Data Library. From there, daily returns of 5, 10, and 49 value-weighted industry portfolios are obtained based on different degrees of industry classification. 9 of the 49 industries are omitted due to missing observations. Those portfolios are therefore considered separately in this study.

The realised volatility in each industry from January 1927 to December 2012 is obtained from the standard deviation formula below:

$$
S R V(\mathrm{t})=\sqrt{\frac{\sum_{i=1}^{N_{t}}\left(R_{j, i, t}-\bar{R}_{j, t}\right)^{2}}{N_{t}-1}},
$$


where $S R V(\mathrm{t})$ is the stock return volatility in period $t ; R_{j, i, t}$ is the daily stock return in industry $j$ on the date $i$ in period $t ; \bar{R}_{j, t}$ is the average return in industry $j$ in period $t$, and $N_{t}$ is the number of trading days in this period.

The three panels in Table 2 report the industry information, including the mean and the standard deviation of stock return volatility in different industries, as well as the short names, definitions, and four-digit SIC codes that are used to assign firms to 5, 10, and 40 industries from French's website. Numbers $(1,2,3)$ following the short names represent the degrees of classification, from general to disaggregated.

In other words, from the 5- to the 10- and the 40-industry classification, the industries are becoming more disaggregated. For instance, Cnsmrl in the 5-industry classification contains Nodur2, Durbl2, and Shops2 in the 10-industry classification, while Hitec1 in the 5-industry classification contains Hitec2 and Telcm 2 in the 10-industry classification. Similarly, Nodur2 in the 10-industry classification consists of some industries in the 40-industry classification, including Agric3, Toy3, Food3, Books3, Clths3, Bldmt3, and Hshld3.

Table 2 reinforces the fact that industries have diverse volatility characteristics. Some industries have higher levels of average stock return volatility. These industries include Hitec1 (Business Equipment and Telecommunication), Durbl2 (Consumer Durables), Toys3 (Recreation), Cnstr3 (Construction), Coal3 (Coal), and Rlest3 (Real Estate). The null hypothesis of Phillips and Perron unit root test is rejected in all industries, indicating that persistence is not severe and our results provide credible guidance.

Moreover, the differences are obvious during the sub-periods. The stock return 
volatility of the aggregate market $\left(S \& P_{-} v w v\right)$ and that of the industries based on the 5-industry classification in three sub-periods are shown in Table 3. The first period (1927-1955) covers the Great Depression, while the third period (1985-2012) features the Great Moderation and the 2008 global financial crisis. The level of volatility of the aggregate markets (Manufl and Otherl) is higher than that of other industries during the first period. Meanwhile, Hitecl grows higher in volatility in the third period. This evidence attests to the diverse fluctuations in stock return volatility of those industries similar to Figure 1, which shows that the Hitecl sector becomes more volatile during the $21^{\text {st }}$ century.

The correlation coefficients between stock return volatility at the aggregate level and macroeconomic variables are shown in Table 4. The default yield, term spread, and industrial production growth volatility correlate positively with the S\&P 500 stock return volatility, while the default return, industrial production growth, and inflation rate have weak and negative impacts on volatility. Moreover, we do not find significant correlations among macroeconomic variables, reinforcing the credibility of the results.

\section{In-Sample Analysis}

\subsection{Model}

The multi-factor forecasting model used in this paper is given by

$$
S R V_{j, t}=\alpha_{j}+\sum_{i=1}^{6} \beta_{j, i} S R V_{j, t-i}+\gamma^{\prime} X_{t-1}+\varepsilon_{j, t}
$$

where $S R V_{j, t}$ is the stock return volatility in industry $j$ in time $t$, and $X_{t-1}$ 
stands for the first-order lag of macroeconomic variables (i.e., default return, default yield, term spread, industrial production growth, volatility of industrial production growth, and inflation rate). The null hypothesis states that there is no Granger causality, meaning that given a vector $X_{t-1}$, the coefficients of macroeconomic variables $\gamma=0$ can be tested using the F-test. Meanwhile, the t-test is used to assess the significance of each macroeconomic determinant.

When $\gamma=0$, the model becomes an AR (6) regression for each industry, which is the benchmark model given by

$$
S R V_{j, t}=\theta_{j}+\sum_{i=1}^{6} \delta_{j, i} S R V_{j, t-i}+u_{j, t}
$$

where $\delta_{j, i}$ is the coefficient associated with each lag of stock return volatility.

\subsection{Results}

Tables 5, 6, and 7 show the in-sample predictive regression results on a monthly horizon of the 5-, 10- and 40-industry classifications respectively. For each industry, the tables display the estimated slope coefficients $\gamma$ and their significance. Since all macroeconomic variables are standardised prior to analysis, the coefficients reported are measured in units of standard deviation.

In addition, the bottom parts of Tables 5 to 7 show the R-squared of the predictive models and of the benchmark models, as well as the relative increase in R-squared expressed as percentages and Granger causality test results for the macroeconomic variables. 
Table 5 depicts the in-sample predictive regression results for the S\&P 500 and 5-industry classification, including Cnsmrl (Consumer Goods), Manuf1 (Manufacturing, etc.), Hitecl (Business Equipment, etc.), Hlthl (Health Care, etc.), and Other1. The results show that both default return and default yield have significant effects on the volatility of the S\&P 500 value-weighted stock returns. This can also be found in all the five industries. The impact of default yield is relatively larger on the stock return volatility in the consumer goods (Cnsmr1) and manufacturing (Manuf1) industries, while the influences of default return on stock return volatility are almost the same within the S\&P 500 and the industries (except Other1). For instance, a coefficient estimate of 0.083 implies that a one-standard deviation shock to the default yield spread increases the volatility forecast of manufacturing (Manuf1) industries in the subsequent period by 0.083 units. There is no obvious evidence to show that other factors (i.e., term spread, industrial production growth, volatility of industrial production growth, and inflation rate) have significant impacts.

The null hypothesis of no Granger causality is rejected in all industries at the 5\% significance level. The R-squared of the model and benchmark model, and the relative change are also reported. Cnsmrl (Consumer Goods), Hlthl (Health Care, etc.), and Manufl (Manufacturing, etc.) show relatively greater increases in R-squared after adding all macroeconomic factors to the benchmark AR (6) model. To a large extent, the results of the coefficient estimates for these five main industries are consistent with Paye (2012), who finds that the macroeconomic variables Granger-cause stock return volatility at monthly horizons, and that the default return and default yield spread are the two variables contributing the most. 
With regards to a more disaggregated industry classification, Table 6 displays the results of in-sample predictive regressions in 10 industries, which contain Nodur2 (Non-Durable Goods), Durbl2 (Durable Goods), Enrgy2 (Oil, Gas, etc.) and Shops2 (Wholesale, Retail, etc.). Similar to the results in 5 major industries, the macroeconomic variables here Granger-cause stock return volatility in 10 industries. However, industry differences become more apparent.

The effects of default return and default yield are significant among the aforementioned 10 industries except Manuf2 (Manufacturing Industry), which is not sensitive to the default return but reacts significantly to the default yield. Since the production and business involved in the manufacturing industry generally requires large initial investments and possess relatively longer profit cycles, this industry may not be sensitive to the realised risk changes reflected by the return difference between long-term corporate bonds and long-term government bonds. However, it is highly sensitive to the changes of long-term expected risk reflected in the yield difference between BAA-rated corporate bonds and long-term U.S. government bonds.

In addition, the stock return volatility of the Hitec2 (Business Equipment) industry reacts significantly to the term spread changes, probably owing to the relatively higher risk and $R \& D$ cost of business equipment firms. The volatility of Utils2 (Utilities) co-varies with the volatility of industrial production growth. This is evident given that utilities contain electric, gas, and water supply services that are directly related to industrial production. Furthermore, the three composites of Cnsmr1, namely Nodur2 (Non-Durable Goods), Durbl2 (Durable Goods) and Shops2 (Wholesale, Retail, etc.), have a relatively greater increase in R-squared. 
Many more clues of different effects can be found in the results (Table 7) under the disaggregated classification of 40 industries, which is an extension of the 10-industry classification. A majority of the industries remain sensitive to the default return and default yield spread. However, some sectors, such as Medeq3 (Medical Equipment), Hardw3 (Computers), and Whlsl3 (Wholesale), react weakly to default return surprises. Since these industries have longer profit cycles and the former two industries require large initial investments, they may not be sensitive to the changes in risk denoted by changes in realised bond return. Moreover, the insensitivity of some industries to default return changes is mainly due to their small shares in the stock market. These industries include Beer3 (Beer and Liquor), Aero3 (Aircraft), and Chips3 (Electronic Equipment). The default yield remains significant among all industries, except Smoke3 (Tobacco Products).

The differences of the impact of the four other factors are barely reflected in the disaggregated classification. Cnstr3 (Construction), Bldmt3 (Construction Materials) and Util3 (Utilities) are all cyclical industrial sectors that rely on raw materials and heavy equipment. They are expected to be strongly influenced by output shocks, which are shown in the coefficients for industrial production-related factors. Medeq 3 (Medical Equipment), Cnstr3 (Construction), Bldmt3 (Construction Materials), and Rlest3 (Real Estate) are greatly affected by inflation shocks. A possible explanation is that these industries normally involve large start-up costs and high proportions of physical capital.

Meanwhile, the Granger causality null hypothesis cannot be rejected for Hardw3 (Computers). It shows little increase in R-squared $(0.87 \%)$ from the benchmark model to the augmented model. This implies that macroeconomic factors cannot 
forecast the subsequent volatility of stock returns in the computer industry.

The explanatory power of the predictive model $(0.176)$ is higher than that of the benchmark model (0.141) for Medeq3 (Medical Equipment). The relative increase of R-squared is quite large (24.823\%). This implies that the present volatility of Medeq 3 (Medical Equipment) stock return depends weakly on the previous volatility, which is consistent with its weak persistency $\left(\rho_{1}=0.2574, \rho_{2}=0.2407\right)$. Nevertheless, this industry is fairly sensitive to the default yield (0.171) and inflation rate (-0.087). This indicates that the high-risk medical equipment industry fluctuates greatly with the risk premium depending on the company's quality (default yield) and price levels (inflation rate).

Other industries with a relatively greater increase in R-squared include Bussv3 (Business Services), Hshld3 (Consumer Goods) and Clths3 (Apparel), where the last two are also included in Nodur2 and Cnsmr1.

In summary, the impact of macroeconomic variables on stock return volatility is largely consistent within a general industry classification, where macroeconomic factors that cause volatility have significant effects, including default return and default yield spread, while other factors do not. However, the differences in impact are obvious within disaggregated sectors (10- and 40-industry classifications). For example, the consumption-related and medical equipment industries show better forecasts after these macroeconomic determinants are added to the benchmark model. 


\section{Out-of-Sample Analysis}

\subsection{Methodology}

The target models in this section are the forecasting regressions in Equation (4), while the macroeconomic variables contained in $X_{t-1}$ are different among industries. Only those found to have a significant effect on industry stock return volatility are included in the forecasting models.

The benchmark models have two specifications. One is the benchmark model in Equation (5) and the other is the new model. The new model adds default return and default yield to the right-hand side of the regression in Equation (5). These two factors have obvious impacts on the stock return volatility of the whole market. Specifically, the models are expressed as

Model 1 (benchmark model 1): $S R V_{j, t}=\theta_{j}+\sum_{i=1}^{6} \delta_{j, i} S R V_{j, t-i}+u_{j, t}$,

Model 2 (benchmark model 2): $S R V_{j, t}=\theta_{j}+\sum_{i=1}^{6} \delta_{j, i} S R V_{j, t-i}+\varphi_{j} d f r_{t-1}+\eta_{j} d f y_{t-1}+u_{j, t}$,

Model 3 (new forecasting model): $S R V_{j, t}=\alpha_{j}+\sum_{i=1}^{6} \beta_{j, i} S R V_{j, t-i}+\varpi^{\prime} X_{t-1}+\varepsilon_{j, t}$.

where $X_{t-1}$ varies among industries, incorporating factors other than default return and default yield, based on the results in Section 4.

Under the null hypothesis, the additional parameters in the new model cannot predict the absence of Granger causality. The benchmark and alternative models should have equal population mean squared prediction error (MSPE). Asymptotically 
valid inferences are constructed under the conditions of asymptotic standard normality. However, the conditions are violated because the models are nested. It is recommended that the tests are adjusted because of the noise associated with the larger model's forecast (Clark and West, 2007). Thus, one-step-ahead forecasts are used, and the sample MSPEs for the two models are given by

$\hat{\sigma}_{j, 1}^{2} \equiv P^{-1} \sum\left(S R V_{j, t+1}-\widehat{S R V_{1, j, t+1}}\right)^{2}, \hat{\sigma}_{j, 2}^{2} \equiv P^{-1} \sum\left(S R V_{j, t+1}-S \widehat{R V}_{2, j, t+1}\right)^{2}$,

$\hat{\sigma}_{j, 2}^{2}-$ adjustment $_{i}=P^{-1} \sum\left(S R V_{j, t+1}-\widehat{S R V_{2, j, t+1}}\right)^{2}-P^{-1} \sum\left(\widehat{S R V_{1, j, t+1}}-\right.$

$\left.\widehat{S R V_{2, j, t+1}}\right)^{2}$

The new forecasting model has a smaller MSPE than the benchmark model. Clark and West (2007) propose testing the null hypothesis with $\hat{\sigma}_{j, 1}^{2}-\left(\hat{\sigma}_{j, 2}^{2}-\right.$ adjustment $\left._{i}\right)$ instead of $\hat{\sigma}_{j, 1}^{2}-\hat{\sigma}_{j, 2}^{2}$, rejecting the null hypothesis that the test statistic is significantly positive. To simplify, the term is defined as

$\hat{f}_{t+1}=$

$\sum\left(S R V_{j, t+1}-S \widehat{R V}_{1, j, t+1}\right)^{2}-\left[P^{-1} \sum\left(S R V_{j, t+1}-\widehat{S R V_{2, j, t+1}}\right)^{2}-P^{-1} \sum\left(\widehat{S R V_{1, j, t+1}}-\right.\right.$

$\left.\left.\widehat{S R V_{2, j, t+1}}\right)^{2}\right]$

Hence, $\hat{\sigma}_{j, 1}^{2}-\left(\hat{\sigma}_{j, 2}^{2}-\right.$ adjustment $\left._{i}\right)$ is the sample average of $\hat{f}_{t+1}$. The test procedure for equal MSPE is to regress $\hat{f}_{t+1}$ on a constant and use the resulting t-statistics for the zero coefficient test. The null is rejected if the statistic is bigger than 1.282 (for a one-sided test under the $10 \%$ significance level), 1.645 (for a one-sided test under the 5\% significance level), or 2.326 (for a one-sided test under the $1 \%$ significance level). 
In this paper, the Clark and West (2007) test is conducted on two groups of models, on Model 1 and Model 3, and on Model 2 and Model 3, respectively. The test examines whether the target forecasting models achieve higher predictive accuracy over industries of different sorts than the benchmark models do.

Forecasting models are analysed through a rolling or recursive process within a regression window of 20 years (240 months). The results in several periods are reported, including those in the periods from 1947 to 2012,1972 to 2012,1982 to 2012, and 1972 to 2002. Since the forecasting performance is affected by the 1973 1975 oil shock (Welch and Goyal, 2008), the sample is split in the 1970s in order to test the sensitivity of the results to the inclusion of the 1970s data.

\subsection{Results}

Tables 8a to 8d report the out-of-sample results for selected industries, using rolling and recursive estimations. In each table, the format of the benchmark models and new forecasting model, as well as the Clark and West (2007) test statistics (multiplied by one million) and their significance levels are presented according to industries. The Clark and West (2007) test results largely affirm the in-sample findings - that the new forecasting models which including macroeconomic variables improve predictive accuracy, when compared to the benchmark models of the AR (6) process. This finding indicates that these macroeconomic variables Granger-cause industry stock return volatility out of sample.

The upper panel of each table shows the Clark and West (2007) test results for

the comparison between the AR (6) benchmark model and the new forecasting model. Mostly, they indicate that the new forecasting models, with the inclusion of some 
macroeconomic factors, outperform the AR (6) benchmark models. In particular, for Manuf2 (Manufacturing, etc.), Fin3 (Trading) and Rlest3 (Real Estate), the null hypothesis is rejected in a rolling or recursive estimation for most out-of-sample periods. Meanwhile, some other industries, such as Medeq3 (Medical Equipment), Cnstr3 (Construction) and Utils2 (Utilities), have better performance in the new forecasting models.

The results in Tables $8 \mathrm{~s}$ to $8 \mathrm{~d}$ reveal that most new forecasting models improve the predictive accuracy after the macroeconomic variables are changed. Based on the results in Section 4.1, Manuf2 (Manufacturing, etc.), Hardw3 (Computers), Fin3 (Trading), and Rlest3 (Real Estate) all show convincing evidence that the modified models predict better. Other industries, such as Cnstr3 (Construction), show improvements only in the recursive estimations in the two sub-periods (1972-2012 and 1982-2012). The results show that the forecasts incorporating AR (6), default return, default yield, volatility of industrial production growth and inflation are relatively more accurate during the periods.

A comparison of results from the 1972 - 2002 and 1982 - 2012 periods demonstrates that the predictive power for stock return volatility is sensitive to the inclusion of the 1970s. For instance, the volatility of Manuf2 (Manufacturing, etc.) seems to have better prediction with AR (6) and the default yield in the 1982 - 2012 period, using both rolling and recursive approaches. However, the same phenomenon cannot be found during the 1972 - 2002 period.

The discrepancy between results obtained from the rolling and recursive approaches is substantial. Generally, under a recursive scheme, the benchmark models of AR (6) and those with default return and default yield underperform the 
new forecasting models. Nevertheless, in some cases, the results under the rolling estimation display more significant model differences. For example, the augmented model of Fin3 (Trading) industry outperforms the AR (6) regressions in the same periods, except for the recursive scheme during the 1972 - 2012 and 1972 - 2002 periods, which cover the turbulent times during the 1970s. Meanwhile, the augmented models improve the reliability of predictions in each sub-period, by adding the factors of industrial production growth and inflation rate only under the recursive scheme. Under the rolling estimation, the forecast sample is limited to 240 months (20 years) of data throughout the whole sample period, while under the recursive scheme, the forecast sample grows continually one step ahead. Hence, the forecasts under the recursive scheme might become less volatile and superior in the out-of-sample performance as the sample size increases. This intuition is pronounced in many industries, including Utils2 (Utilities), Medeq3 (Medical Equipment) and Cnstr3 (Construction). Such prominence could be due to the greater volatility of stock return in those industries.

\section{Conclusion}

Stock return volatility is largely countercyclical and is often connected to macroeconomic determinants. This paper employs an augmented model to detect the impacts of macroeconomic factors on stock return volatility in different industries. The results show that the difference in the impacts of macroeconomic factors is obvious among disaggregated industry sectors. Different levels of sensitivity of industry-level stock return volatility are found in variables related to general economic conditions, monetary policies, and price levels. The Clark and West (2007) 
test is employed to verify whether the new forecasting models, which vary among industries based on the in-sample results, can have better predictions than the two benchmark models. Our results show that default return and default yield have significant impacts on stock return volatility. The discrepancies of the influence among disaggregated industries are conspicuous. For example, the Cnstr3 (Construction), Bldmt3 (Construction Materials) and Util3 (Utilities), which are all cyclical industrial sectors that rely on raw materials and heavy equipment, are strongly influenced by industrial production-related factors. Meanwhile, Medeq3 (Medical Equipment), Cnstr3 (Construction), Bldmt3 (Construction Materials), and Rlest3 (Real Estate) are largely affected by inflation shocks.

As for the out-of-sample analysis, the new forecasting models perform better than the benchmark models constructed by auto-regressions or basic settings for the aggregate market. However, the superiority is not exactly the same under the two approaches in four sub-periods.

This paper extends the results of previous studies mainly by Paye (2012) via focusing on the industry-level analysis. The investigation proves that the impacts of the examined macroeconomic factors differentiate themselves from one industry to another. Furthermore, to some degree, the modified models improve the predictive accuracy. The next intriguing step for future studies is to explore the specific reasons behind the discrepancies, for example, by including industry specific variables. 


\section{References}

Anderson, T. G., Bollerslev, T., and Diebold, F. X., 2007. Roughing it up: Including jump components in the measurement, modelling, and forecasting of return volatility. Review of Economics and Statistics 89(4), 701-720.

Boudoukh, J., Richardson, M., and Whitelaw, R. F., 1994. Industry returns and the fisher effect. Journal of Finance 49(5), 1595-1615.

Campbell, J. Y., Lettau, M., Malkiel, B. G., and Xu, Y., 2001. Have individual stocks become more volatile? An empirical exploration of idiosyncratic risk. Journal of Finance 56(1), 1-43.

Chen, N. F., Roll, R., and Ross, S. A. 1986. Economic forces and the stock market. Journal of Business 59(3), 383-403.

Clark, T. E., and West, K. D., 2007. Approximately normal tests for equal predictive accuracy in nested models. Journal of Econometrics 138(1), 291-311.

Czaja, M. G., and Scholz, H., 2007. Sensitivity of stock returns to changes in the term structure of interest rates-evidence from the German market. Operations Research Proceedings 2006, 305-310.

Dinenis, E., and Staikouras, S. K., 1998. Interest rate changes and common stock returns of financial institutions: evidence from the UK. European Journal of Finance 4(2), 113-127.

Engle, R. F, Gyhsels, E., and Sohn, B., 2008. On the economic sources of stock market volatility. AFA 2008 New Orleans Meetings Paper.

Engle, R. F., and Rangel, J. G., 2008. The spline-GARCH model for low-frequency volatility and its global macroeconomic causes. Review of Financial Studies 21(3), 1187-1222.

Faff, R. W., and Brailsford, T. J., 1999. Oil price risk and the Australian stock 
market. Journal of Energy Finance and Development 4(1), 69-87.

Fama, E. F., and French, K. R., 1997. Industry costs of equity. Journal of Financial Economics 43(2), 153-193.

Fornari, F., and Mele, A., 2013. Financial volatility and economic activity. Journal of Financial Management, Markets and Institutions 2, 155-198.

Hess, M. K., 2003. Sector specific impacts of macroeconomic fundamentals on the Swiss stock market. Financial Markets and Portfolio Management 17(2), 234-245.

Humpe, A., and Macmillan, P., 2009. Can macroeconomic variables explain long-term stock market movements? A comparison of the US and Japan. Applied Financial Economics 19(2), 111-119.

Kearney, C., and Daly, K., 1998. The causes of stock market volatility in Australia. Applied Financial Economics 8(6), 597-605.

Merton, R. C., 1980. On estimating the expected return on the market: an exploratory investigation. Journal of Financial Economics 8(4), 323-361.

Oertmann, P., Rendu, C., and Zimmermann, H., 2000. Interest rate risk of European financial corporations. European Financial Management 6(4), 459-478.

Paye, B. S., 2012. 'Déjà vol': Predictive regressions for aggregate stock market volatility using macroeconomic variables. Journal of Financial Economics 106(3), 527-546.

Sadorsky, P., 2001. Risk factors in stock returns of Canadian oil and gas companies. Energy Economics 23(1), 17-28.

Sadorsky, P., 2003. The macroeconomic determinants of technology stock price volatility. Review of Financial Economics 12(2), 191-205.

Schwert, G. W., 1989. Why does stock market volatility change over time? 
Journal of Finance 44(5), 1115-1153.

Sohn, B., 2009. Cross-section of equity returns: stock market volatility and priced factors. Working Paper, Georgetown University.

Sweeney, R. J., and Warga, A. D., 1986. The pricing of interest-rate risk: evidence from the stock market. Journal of Finance 41(2), 393-410.

Welch, I., and Goyal, A., 2008. A comprehensive look at the empirical performance of equity premium prediction. Review of Financial Studies 21(4), 1455-1508. 
Stock Return Volatility of S\&P 500 Value-weighted Market Portfolio

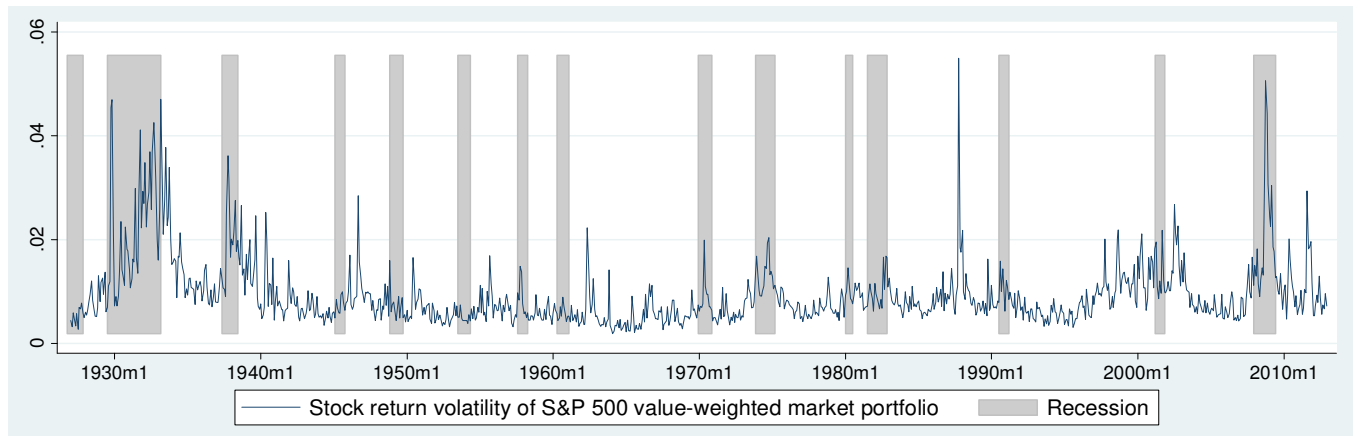

Stock Return Volatility of Manuf1 (manufacturing, energy and utilities)

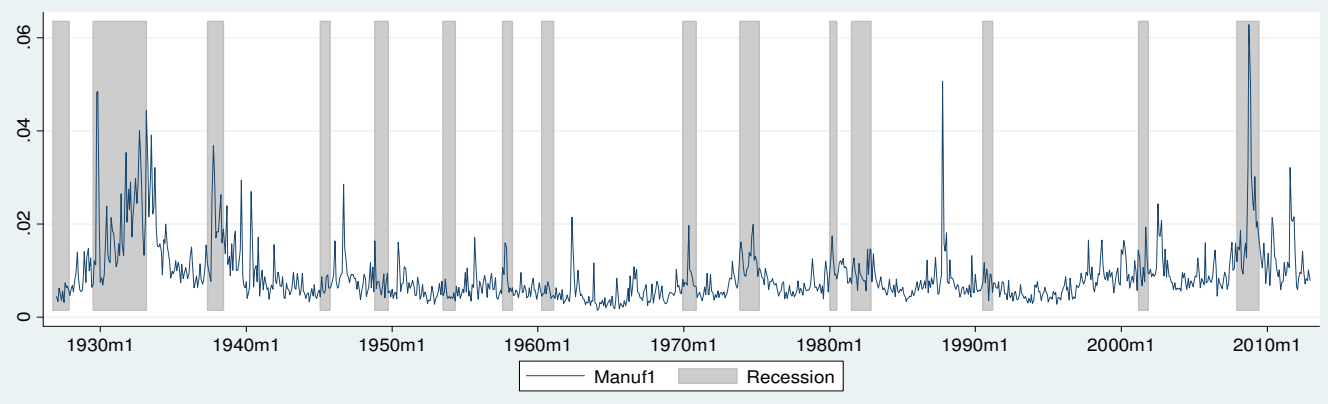

Stock Return Volatility of Hitec1 (business equipment, telephone and television transmission)

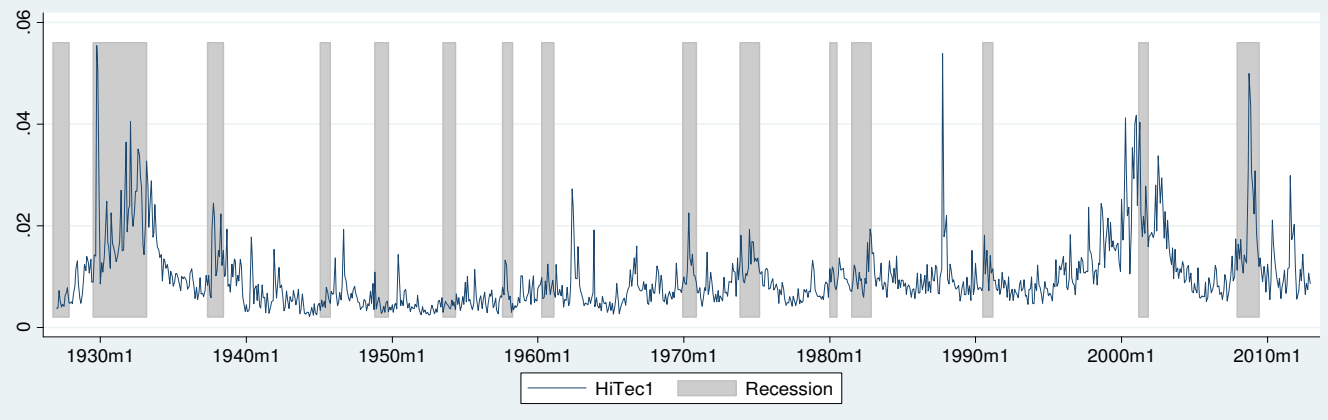

Stock Return Volatility of S\&P 500 Value-weighted Market Portfolio and Cnstr3 (construction)

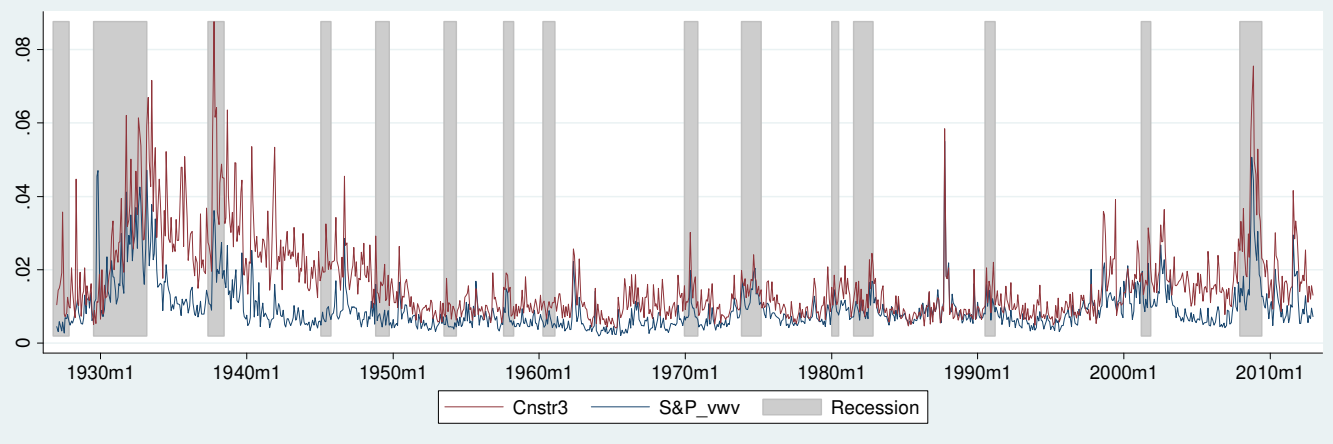

Figure 1: Fluctuations of Stock Return Volatility (Range: 192701-201212) 
Table 1: Macroeconomic Variables: Descriptive Statistics (Range: 192701-201212)

\begin{tabular}{|c|c|c|c|c|c|c|c|}
\hline \multirow[b]{2}{*}{ Symbol } & \multirow[b]{2}{*}{ Variable Name } & \multirow[b]{2}{*}{ Mean } & \multirow[b]{2}{*}{ Std. Dev. } & \multirow[b]{2}{*}{ Min } & \multirow[b]{2}{*}{$\operatorname{Max}$} & \multicolumn{2}{|c|}{ Phillips and Perron test } \\
\hline & & & & & & $Z_{t}$ & $p$-value \\
\hline dfr & Default Return & -0.0050 & 0.2137 & -1.2854 & 2.6677 & -37.04 & 0.00 \\
\hline dfy & Default Yield & 0.0180 & 0.0097 & 0.0035 & 0.0759 & -3.99 & 0.00 \\
\hline tms & Term Spread & 0.0168 & 0.0132 & -0.0365 & 0.0455 & -4.77 & 0.00 \\
\hline ipg & Industrial production growth & 0.0026 & 0.0182 & -0.1096 & 0.1532 & -17.29 & 0.00 \\
\hline ipgvol & $\begin{array}{l}\text { Industrial Production Growth } \\
\text { Volatility }\end{array}$ & 0.0090 & 0.0117 & 0.0000 & 0.1278 & -21.52 & 0.00 \\
\hline infl & Inflation Rate & 0.0024 & 0.0105 & -0.0548 & 0.1028 & -23.31 & 0.00 \\
\hline
\end{tabular}

Table 1 presents the descriptive statistics for the macroeconomic variables over the period 1927 - 2012. The Phillips and Perron unit root test is conducted for all macroeconomic variables. The final two columns report the $Z_{t}$ test statistics for the Phillips and Perron unit root test and the associated Mackinnon approximate p-value, respectively. As shown, the test results reject the null hypothesis of a unit root for all variables, implying that persistence is not severe. 
Table 2: Stock Return Volatility: Industry Classifications and Descriptive Statistics

\begin{tabular}{|c|c|c|c|}
\hline Industry & Mean & Std. Dev. & Definition \\
\hline Cnsmr1 & 0.0086 & 0.0054 & $\begin{array}{l}\text { Consumer Durables, Nondurables, Wholesale, Retail, and Some Services } \\
\text { (Laundries, Repair Shops) }\end{array}$ \\
\hline Manuf1 & 0.0089 & 0.0063 & Manufacturing, Energy, and Utilities \\
\hline Hitec1 & 0.0099 & 0.0067 & Business Equipment, Telephone and Television Transmission \\
\hline Hlth1 & 0.0093 & 0.0057 & Healthcare, Medical Equipment, and Drugs \\
\hline Other1 & 0.0098 & 0.0072 & $\begin{array}{l}\text { Other -- Mines, Construction, Building Materials, Transportation, Hotels, } \\
\text { Bus Services, Entertainment, Finance }\end{array}$ \\
\hline
\end{tabular}




\begin{tabular}{|c|c|c|c|}
\hline Industry & Mean & Std. Dev. & Definition \\
\hline Nodur2 & 0.0072 & 0.0047 & Consumer Nondurables -- Food, Tobacco, Textiles, Apparel, Leather, Toys \\
\hline Durbl2 & 0.0128 & 0.0081 & Consumer Durables -- Cars, TV's, Furniture, Household Appliances \\
\hline Manuf2 & 0.0097 & 0.0067 & $\begin{array}{l}\text { Manufacturing -- Machinery, Trucks, Planes, Chemicals, Off Furn, Paper, } \\
\text { Com Printing }\end{array}$ \\
\hline Enrgy2 & 0.0108 & 0.0066 & Oil, Gas, and Coal Extraction and Products \\
\hline Hitec2 & 0.0126 & 0.0081 & Business Equipment -- Computers, Software, and Electronic Equipment \\
\hline Telcm2 & 0.0085 & 0.0060 & Telephone and Television Transmission \\
\hline Shops2 & 0.0091 & 0.0059 & Wholesale, Retail, and Some Services (Laundries, Repair Shops) \\
\hline Hlth2 & 0.0093 & 0.0057 & Healthcare, Medical Equipment, and Drugs \\
\hline Utils2 & 0.0079 & 0.0071 & Utilities \\
\hline Other2 & 0.0098 & 0.0072 & $\begin{array}{l}\text { Other -- Mines, Construction, Building Materials, Transportation, Hotels, } \\
\text { Bus Services, Entertainment, Finance }\end{array}$ \\
\hline
\end{tabular}




\begin{tabular}{cccl}
\hline Industry & Mean & Std. Dev. & Definition \\
\hline Agric3 & 0.0130 & 0.0075 & Agriculture \\
Food3 & 0.0075 & 0.0051 & Food Products \\
Beer3 & 0.0119 & 0.0082 & Beer \& Liquor \\
Smoke3 & 0.0104 & 0.0062 & Tobacco Products \\
Toys3 & 0.0171 & 0.0120 & Recreation \\
Fun3 & 0.0150 & 0.0098 & Entertainment \\
Books3 & 0.0125 & 0.0082 & Printing and Publishing \\
Hshld3 & 0.0098 & 0.0063 & Consumer Goods \\
Clths3 & 0.0095 & 0.0062 & Apparel \\
& & & \\
Medeq3 & 0.0125 & 0.0097 & Medical Equipment \\
Drugs3 & 0.0097 & 0.0059 & Pharmaceutical Products \\
Chems3 & 0.0106 & 0.0072 & Chemicals \\
Txtls3 & 0.0106 & 0.0073 & Textiles \\
Bldmt3 & 0.0102 & 0.0070 & Construction Materials \\
Cnstr3 & 0.0164 & 0.0110 & Construction \\
Steel3 & 0.0133 & 0.0098 & Steel Works Etc. \\
\hline
\end{tabular}




\begin{tabular}{cccl} 
Mach3 & 0.0110 & 0.0080 & Machinery \\
Elceq3 & 0.0132 & 0.0084 & Electrical Equipment \\
Autos3 & 0.0133 & 0.0083 & Automobiles and Trucks \\
Aero3 & 0.0147 & 0.0097 & Aircraft \\
Ships3 & 0.0131 & 0.0072 & Shipbuilding, Railroad Equipment \\
Mines3 & 0.0127 & 0.0087 & Non-Metallic and Industrial Metal Mining \\
Coal3 & 0.0169 & 0.0130 & Coal \\
Oil3 & 0.0109 & 0.0066 & Petroleum and Natural Gas \\
Util3 & 0.0079 & 0.0071 & Utilities \\
Telcm3 & 0.0085 & 0.0060 & Communication \\
\hline
\end{tabular}

\begin{tabular}{cccl}
\hline Industry & Mean & Std. Dev. & Definition \\
\hline Bussv3 & 0.0120 & 0.0144 & Business Services \\
Hardw3 & 0.0132 & 0.0082 & Computers \\
Chips3 & 0.0149 & 0.0095 & Electronic Equipment
\end{tabular}




\begin{tabular}{cccl} 
Labeq3 & 0.0126 & 0.0071 & Measuring and Control Equipment \\
Boxes3 & 0.0109 & 0.0062 & Shipping Containers \\
Trans3 & 0.0114 & 0.0071 & Transportation \\
Whls13 & 0.0117 & 0.0105 & Wholesale \\
Rtail3 & 0.0095 & 0.0062 & Retail \\
Meals3 & 0.0118 & 0.0065 & Restaurants, Hotels, Motels \\
Banks3 & 0.0114 & 0.0093 & Banking \\
Insur3 & 0.0111 & 0.0078 & Insurance \\
Rlest3 & 0.0163 & 0.0131 & Real Estate \\
Fin3 & 0.0122 & 0.0097 & Trading \\
\hline Other3 & 0.0126 & 0.0079 & Almost Nothing \\
\hline
\end{tabular}

Numbers $(1,2,3)$ following the short names represent the degrees of classification, from general to disaggregated. The Phillips and Perron unit root test is rejected for all the industries, indicating that persistence is not severe and our results can provide credible guidance. 
Table 3: Stock Return Volatility: Descriptive Statistics in Sub-periods (Five Industries)

\begin{tabular}{c|cccc|cccccccccc}
\hline $\begin{array}{c}\text { Stock } \\
\text { Return } \\
\text { Volatility }\end{array}$ & \multicolumn{7}{|c}{$\mathbf{1 9 2 7 - 1 9 5 5}$} & & \multicolumn{3}{c}{$\mathbf{1 9 5 6 - 1 9 8 4}$} & & & \multicolumn{1}{c}{$\mathbf{1 9 8 5 - 2 0 1 2}$} \\
\hline Industry & Mean & Std. Dev. & Max & Min & Mean & Std. Dev. & Max & Min & Mean & Std. Dev. & Max & Min \\
\hline Cnsmr1 & 0.0096 & 0.0069 & 0.0459 & 0.0025 & 0.0070 & 0.0030 & 0.0196 & 0.0023 & 0.0093 & 0.0051 & 0.0514 & 0.0030 \\
Manuf1 & 0.0107 & 0.0078 & 0.0485 & 0.0028 & 0.0068 & 0.0032 & 0.0216 & 0.0015 & 0.0093 & 0.0064 & 0.0629 & 0.0027 \\
Hitec1 & 0.0092 & 0.0074 & 0.0555 & 0.0021 & 0.0082 & 0.0035 & 0.0273 & 0.0027 & 0.0125 & 0.0076 & 0.0539 & 0.0046 \\
Hlth1 & 0.0093 & 0.0072 & 0.0495 & 0.0027 & 0.0082 & 0.0037 & 0.0277 & 0.0025 & 0.0105 & 0.0054 & 0.0542 & 0.0030 \\
Other1 & 0.0115 & 0.0084 & 0.0508 & 0.0029 & 0.0071 & 0.0032 & 0.0258 & 0.0023 & 0.0109 & 0.0080 & 0.0556 & 0.0029 \\
S\&P_vwv & 0.0112 & 0.0082 & 0.0471 & 0.0027 & 0.0071 & 0.0032 & 0.0223 & 0.0019 & 0.0100 & 0.0062 & 0.0550 & 0.0031 \\
\hline \hline
\end{tabular}

Table 3 reports the stock return volatility of the aggregate market $\left(S \& P_{-} v w v\right)$ and the industries based on the 5-industry classification in three sub-periods. The first period, 1927 - 1955, covers the Great Depression, while the last period, 1985 - 2012, features the Great Moderation and the 2008 global financial crisis. 
Table 4: Correlation Coefficients

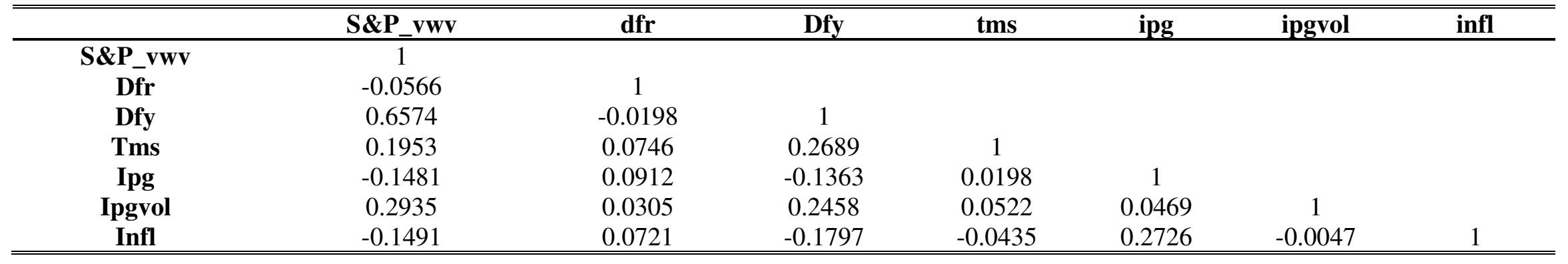

Table 4 reflects the correlation coefficients between each two variables. 
Table 5: In-sample Predictive Regression Results for 5-industry Classification

\begin{tabular}{|c|c|c|c|c|c|c|c|}
\hline Symbol & Variable Name & S\&P_vwv & Cnsmr1 & Manuf1 & Hitec1 & Hlth1 & Other1 \\
\hline Dfy & Default yield spread & $0.088 * * *$ & $0.080 * * *$ & $0.083 * * *$ & $0.053 * * *$ & $0.046 * *$ & $0.077 * * *$ \\
\hline Tms & Term spread & -0.002 & -0.001 & -0.002 & -0.014 & -0.002 & 0.000 \\
\hline Ipg & $\begin{array}{l}\text { Industrial production } \\
\text { growth }\end{array}$ & -0.001 & 0.000 & -0.001 & 0.002 & -0.009 & 0.009 \\
\hline Infl & Inflation rate & -0.015 & -0.001 & -0.012 & -0.015 & -0.005 & -0.022 \\
\hline R-squared & & 0.584 & 0.494 & 0.563 & 0.607 & 0.475 & 0.616 \\
\hline $\begin{array}{l}\text { Benchmark } \\
\text { R-squared }\end{array}$ & & 0.575 & 0.481 & 0.553 & 0.602 & 0.466 & 0.607 \\
\hline
\end{tabular}

Table 5 depicts the in-sample predictive regression results for the S\&P 500 and 5-industry classification. It reports the estimated slope coefficients and their significance, the R-squared of the predictive models and those of the benchmark models, as well as the relative increase in R-squared, expressed as percentage and Granger causality test results for the macroeconomic variables. ***, ** and * represent statistical significance at the 1\%,5\% and 10\% level respectively. Similarly, the results of disaggregated industries are presented in Table 6 and Table 7. 
Table 6: In-sample Predictive Regression Results for 10-industry Classification

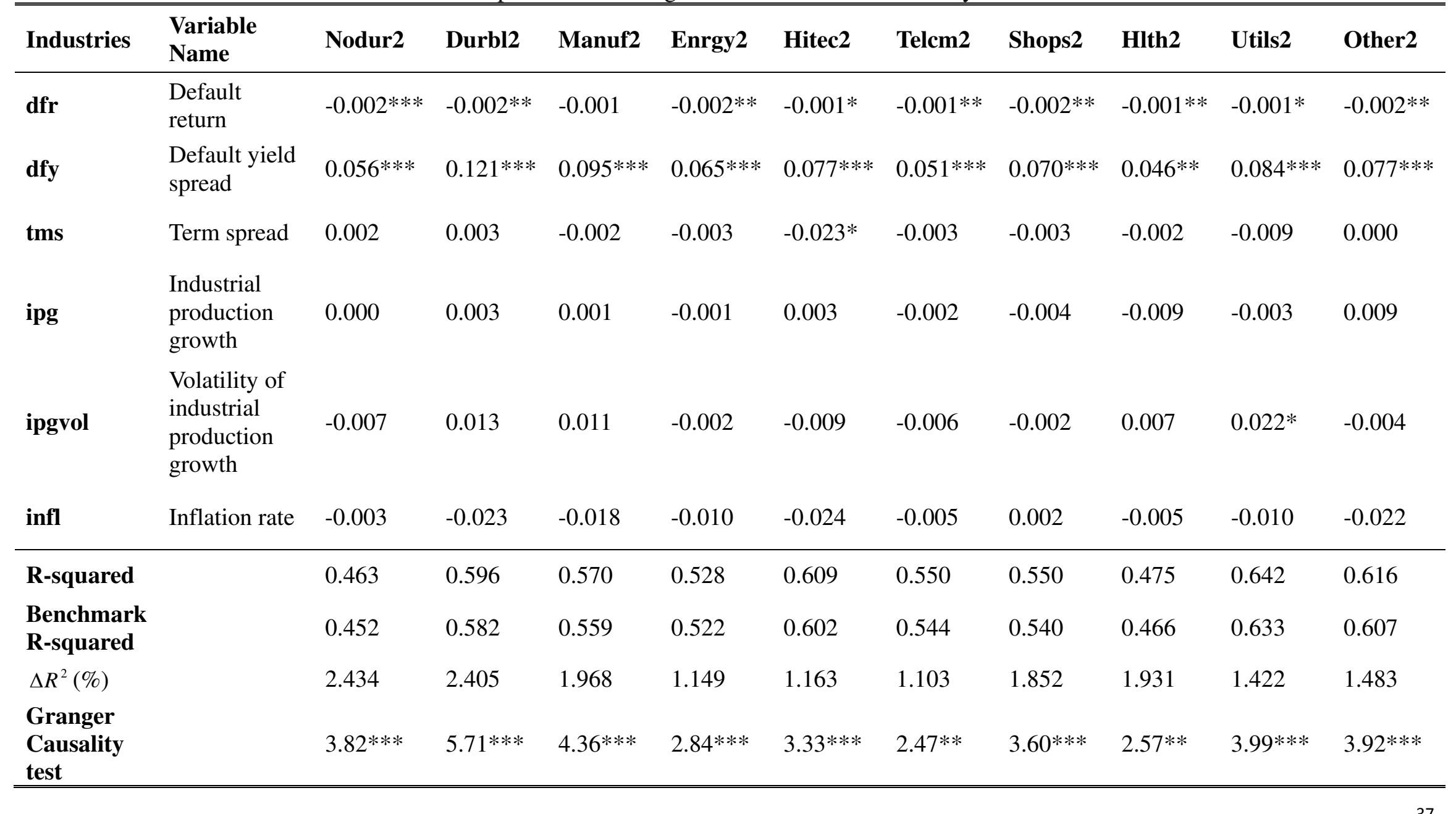


Table 7: In-sample Predictive Regression Results for 40-industry Classification

\begin{tabular}{|c|c|c|c|c|c|c|c|c|c|c|c|}
\hline Industries & $\begin{array}{l}\text { Variable } \\
\text { Name }\end{array}$ & Agric3 & Food3 & Beer3 & Smoke3 & Toys3 & Fun3 & Books3 & Hshld3 & Clths3 & Medeq3 \\
\hline dfr & Default return & $-0.002 * * *$ & $-0.002 * * *$ & -0.001 & $-0.002 * * *$ & $-0.003 * * *$ & $-0.002 *$ & $-0.002 * * *$ & $-0.002 * * *$ & $-0.004 * *$ & -0.002 \\
\hline dfy & $\begin{array}{l}\text { Default yield } \\
\text { spread }\end{array}$ & $0.065^{* * *}$ & $0.067 * * *$ & $0.072 * * *$ & 0.016 & $0.154 * * *$ & $0.165^{* * *}$ & $0.076^{* * *}$ & $0.082 * * *$ & $0.064 * * *$ & $0.171 * * *$ \\
\hline $\operatorname{tms}$ & Term spread & -0.017 & 0.000 & -0.009 & 0.000 & -0.019 & -0.010 & 0.006 & -0.019 & 0.003 & -0.003 \\
\hline ipg & $\begin{array}{l}\text { Industrial } \\
\text { production } \\
\text { growth }\end{array}$ & -0.004 & 0.002 & $0.020 * *$ & -0.007 & 0.005 & 0.005 & $0.033 * * *$ & 0.006 & -0.003 & -0.002 \\
\hline ipgvol & $\begin{array}{l}\text { Volatility of } \\
\text { industrial } \\
\text { production } \\
\text { growth }\end{array}$ & -0.002 & -0.007 & 0.022 & -0.018 & $0.057 * * *$ & 0.014 & 0.012 & 0.000 & -0.001 & 0.041 \\
\hline infl & Inflation rate & -0.018 & -0.006 & -0.007 & -0.001 & -0.020 & -0.005 & -0.029 & -0.010 & -0.008 & $-0.087 * * *$ \\
\hline R-squared & & 0.530 & 0.488 & 0.604 & 0.517 & 0.625 & 0.591 & 0.544 & 0.461 & 0.503 & 0.176 \\
\hline $\begin{array}{l}\text { Benchmark } \\
\text { R-squared }\end{array}$ & & 0.519 & 0.474 & 0.597 & 0.512 & 0.610 & 0.579 & 0.529 & 0.445 & 0.478 & 0.141 \\
\hline$\Delta R^{2}(\%)$ & & 2.119 & 2.954 & 1.173 & 0.977 & 2.459 & 2.073 & 2.836 & 3.596 & 5.230 & 24.823 \\
\hline $\begin{array}{l}\text { Granger } \\
\text { Causality } \\
\text { test }\end{array}$ & & $4.02 * * *$ & $4.52 * * *$ & $2.72 * *$ & $2.30 * *$ & $6.67 * * *$ & $5.14 * * *$ & $5.32 * * *$ & $4.99 * * *$ & $7.62 * * *$ & $7.09 * * *$ \\
\hline
\end{tabular}


Table 7: In-sample Predictive Regression Results for 40-industry Classification (Continued)

\begin{tabular}{|c|c|c|c|c|c|c|c|c|c|c|c|}
\hline Industries & $\begin{array}{l}\text { Variable } \\
\text { Name }\end{array}$ & Drugs3 & Chems3 & Txtls3 & Bldmt3 & Cnstr3 & Steel3 & Mach3 & Elceq3 & Autos3 & Aero3 \\
\hline dfr & $\begin{array}{l}\text { Default } \\
\text { return }\end{array}$ & $-0.001 *$ & $-0.002 * *$ & $-0.003 * * *$ & $-0.002 * * *$ & $-0.002 *$ & $-0.002 * * *$ & $-0.002 * *$ & $-0.002 * *$ & $-0.002 * *$ & -0.001 \\
\hline dfy & $\begin{array}{l}\text { Default yield } \\
\text { spread }\end{array}$ & $0.040 * *$ & $0.076 * * *$ & $0.076 * * *$ & $0.094 * * *$ & $0.093 * * *$ & $0.108 * * *$ & $0.115^{* * *}$ & $0.098 * * *$ & $0.124 * * *$ & $0.103 * * *$ \\
\hline $\operatorname{tms}$ & Term spread & -0.003 & -0.007 & 0.009 & 0.006 & 0.007 & 0.007 & 0.003 & -0.012 & 0.004 & $-0.030^{*}$ \\
\hline ipg & $\begin{array}{l}\text { Industrial } \\
\text { production } \\
\text { growth }\end{array}$ & -0.010 & -0.004 & 0.010 & $0.015^{*}$ & -0.007 & -0.006 & 0.006 & 0.003 & 0.003 & 0.007 \\
\hline ipgvol & $\begin{array}{l}\text { Volatility of } \\
\text { industrial } \\
\text { production } \\
\text { growth }\end{array}$ & 0.008 & 0.000 & 0.002 & 0.007 & $0.062 * * *$ & -0.003 & -0.001 & 0.007 & 0.009 & 0.000 \\
\hline infl & Inflation rate & 0.002 & -0.014 & $-0.030 *$ & $-0.029 *$ & $-0.037 *$ & $-0.033 *$ & $-0.028 *$ & $-0.035^{* *}$ & -0.027 & -0.029 \\
\hline R-squared & & 0.497 & 0.608 & 0.572 & 0.563 & 0.660 & 0.637 & 0.607 & 0.618 & 0.597 & 0.569 \\
\hline $\begin{array}{l}\text { Benchmark } \\
\text { R-squared }\end{array}$ & & 0.489 & 0.599 & 0.556 & 0.547 & 0.645 & 0.626 & 0.594 & 0.607 & 0.582 & 0.560 \\
\hline$\Delta R^{2}(\%)$ & & 1.636 & 1.503 & 2.878 & 2.925 & 2.326 & 1.757 & 2.189 & 1.812 & 2.577 & 1.607 \\
\hline $\begin{array}{l}\text { Granger } \\
\text { Causality } \\
\text { test }\end{array}$ & & $2.18 * *$ & $3.72 * * *$ & $5.92 * * *$ & $6.22 * * *$ & $5.60 * * *$ & $5.48 * * *$ & $5.54 * * *$ & $4.91 * * *$ & $6.24 * * *$ & $2.73 * *$ \\
\hline
\end{tabular}


Table 7: In-sample Predictive Regression Results for 40-industry Classification (Continued)

\begin{tabular}{|c|c|c|c|c|c|c|c|c|c|c|c|}
\hline Industries & $\begin{array}{l}\text { Variable } \\
\text { Name }\end{array}$ & Ships3 & Mines3 & Coal3 & Oil3 & Util3 & Telcm3 & Bussv3 & Hardw3 & Chips3 & Labeq3 \\
\hline dfr & $\begin{array}{l}\text { Default } \\
\text { return }\end{array}$ & -0.001 & $-0.001 *$ & $-0.004 * *$ & $-0.002 * *$ & $-0.001 *$ & $-0.001 * *$ & -0.002 & -0.001 & -0.001 & $-0.002 * * *$ \\
\hline dfy & $\begin{array}{l}\text { Default yield } \\
\text { spread }\end{array}$ & $0.118 * * *$ & $0.065^{* *}$ & $0.174 * * *$ & $0.069 * * *$ & $0.083^{* * *}$ & $0.051 * * *$ & $0.276^{* * *}$ & $0.044 * *$ & $0.067 * *$ & $0.071 * * *$ \\
\hline tms & Term spread & 0.011 & -0.014 & 0.002 & -0.005 & -0.009 & -0.003 & -0.026 & $-0.027 * *$ & -0.024 & -0.014 \\
\hline ipg & $\begin{array}{l}\text { Industrial } \\
\text { production } \\
\text { growth }\end{array}$ & 0.003 & 0.012 & 0.011 & 0.000 & -0.003 & -0.002 & $-0.086 * * *$ & 0.003 & 0.005 & -0.013 \\
\hline ipgvol & $\begin{array}{l}\text { Volatility of } \\
\text { industrial } \\
\text { production } \\
\text { growth }\end{array}$ & 0.004 & -0.014 & 0.004 & -0.005 & $0.022 *$ & -0.006 & $0.064^{*}$ & -0.017 & 0.015 & -0.012 \\
\hline infl & Inflation rate & -0.013 & -0.025 & -0.008 & -0.011 & -0.010 & -0.005 & -0.006 & -0.016 & -0.032 & -0.012 \\
\hline R-squared & & 0.542 & 0.569 & 0.503 & 0.538 & 0.644 & 0.550 & 0.275 & 0.580 & 0.563 & 0.555 \\
\hline $\begin{array}{l}\text { Benchmark } \\
\text { R-squared }\end{array}$ & & 0.529 & 0.563 & 0.489 & 0.531 & 0.635 & 0.544 & 0.236 & 0.575 & 0.554 & 0.541 \\
\hline$\Delta R^{2}(\%)$ & & 2.457 & 1.066 & 2.863 & 1.318 & 1.417 & 1.103 & 16.525 & 0.870 & 1.625 & 2.588 \\
\hline $\begin{array}{l}\text { Granger } \\
\text { Causality } \\
\text { test } \\
\end{array}$ & & $4.64 * * *$ & $2.31 * *$ & $5.13 * * *$ & $2.98 * * *$ & $3.99 * * *$ & $2.48 * *$ & $9.10 * * *$ & 1.71 & $2.53 * *$ & $4.90 * * *$ \\
\hline
\end{tabular}


Table 7: In-sample Predictive Regression Results for 40-industry Classification (Continued)

\begin{tabular}{|c|c|c|c|c|c|c|c|c|c|c|c|}
\hline Industries & $\begin{array}{l}\text { Variable } \\
\text { Name }\end{array}$ & Boxes3 & Trans3 & Whlsl3 & Rtail3 & Meals3 & Banks3 & Insur3 & Rlest3 & Fin3 & Other3 \\
\hline dfr & $\begin{array}{l}\text { Default } \\
\text { return }\end{array}$ & $-0.001 * *$ & $-0.002 * *$ & 0.000 & $-0.002 * * *$ & -0.001 & $-0.002 * * *$ & -0.001 & $-0.004 * * *$ & $-0.002 * *$ & $-0.002 * *$ \\
\hline dfy & $\begin{array}{l}\text { Default yield } \\
\text { spread }\end{array}$ & $0.079 * * *$ & $0.111 * * *$ & $0.171 * * *$ & $0.059 * * *$ & $0.084 * * *$ & $0.071 * * *$ & $0.096 * * *$ & $0.118 * * *$ & $0.066 * *$ & $0.084 * * *$ \\
\hline $\operatorname{tms}$ & Term spread & -0.004 & 0.000 & -0.019 & -0.003 & $-0.021 *$ & -0.017 & -0.019 & 0.000 & -0.022 & -0.018 \\
\hline ipg & $\begin{array}{l}\text { Industrial } \\
\text { production } \\
\text { growth }\end{array}$ & -0.005 & -0.002 & $0.036 * * *$ & -0.005 & 0.008 & 0.007 & -0.005 & 0.021 & $0.026 * *$ & 0.015 \\
\hline ipgvol & $\begin{array}{l}\text { Volatility of } \\
\text { industrial } \\
\text { production } \\
\text { growth }\end{array}$ & -0.011 & 0.000 & 0.019 & -0.004 & 0.004 & 0.012 & -0.009 & 0.030 & -0.018 & 0.019 \\
\hline infl & Inflation rate & -0.005 & -0.006 & -0.014 & 0.003 & -0.013 & $-0.036^{* *}$ & -0.022 & $-0.080 * * *$ & $-0.050 * * *$ & -0.024 \\
\hline R-squared & & 0.507 & 0.583 & 0.489 & 0.564 & 0.514 & 0.692 & 0.576 & 0.669 & 0.620 & 0.551 \\
\hline $\begin{array}{l}\text { Benchmark } \\
\text { R-squared }\end{array}$ & & 0.495 & 0.571 & 0.479 & 0.555 & 0.504 & 0.681 & 0.563 & 0.654 & 0.609 & 0.538 \\
\hline$\Delta R^{2}(\%)$ & & 2.424 & 2.102 & 2.088 & 1.622 & 1.984 & 1.615 & 2.309 & 2.294 & 1.806 & 2.416 \\
\hline $\begin{array}{l}\text { Granger } \\
\text { Causality } \\
\text { test }\end{array}$ & & $3.90 * * *$ & $5.22 * * *$ & $4.70 * * *$ & $3.31 * * *$ & $3.44 * * *$ & $4.80 * * *$ & $4.06 * * *$ & $7.74 * * *$ & $4.14 * * *$ & $4.70 * * *$ \\
\hline
\end{tabular}


Table 8a: Out-of-sample Test Results for Predictive Accuracy

\begin{tabular}{lllll}
\hline \hline Manuf2 & $\begin{array}{l}\mathbf{1 9 4 7 m 1 - 2 0 1 2} \\
\mathbf{m 1 2}\end{array}$ & $\begin{array}{l}\mathbf{1 9 7 2 m 1 - 2 0 1 2} \\
\mathbf{m 1 2}\end{array}$ & $\begin{array}{l}\mathbf{1 9 8 2 m 1 - 2 0 1 2} \\
\mathbf{m 1 2}\end{array}$ & $\begin{array}{l}\mathbf{1 9 7 2 m 1 - 2 0 0 2} \\
\mathbf{m 1 2}\end{array}$ \\
\hline $\begin{array}{l}\text { Benchmark } \\
\text { model }\end{array}$ & $\mathrm{AR}(6)$ & $\mathrm{AR}(6)$ & $\mathrm{AR}(6)$ & $\mathrm{AR}(6)$ \\
$\begin{array}{l}\text { New model } \\
\text { Rolling } \\
\text { estimation } \\
\text { Recursive } \\
\text { estimation }\end{array}$ & $+\mathrm{dfy}$ & $+\mathrm{dfy}$ & $+\mathrm{dfy}$ & $+\mathrm{dfy}$ \\
\hline & $4.04 * *$ & 2.70 & 3.50 & 0.41 \\
\hline $\begin{array}{l}\text { Benchmark } \\
\text { model }\end{array}$ & $\mathbf{1 9 4 7 \mathbf { m } 1 - 2 0 1 2}$ & $\mathbf{1 9 7 2 m 1 - 2 0 1 2}$ & $\mathbf{1 9 8 2 m 1 - 2 0 1 2}$ & $\mathbf{1 9 7 2 m 1 - 2 0 0 2}$ \\
$\begin{array}{l}\text { New model } \\
\text { Rolling } \\
\text { estimation }\end{array}$ & $+\mathrm{dff}, \mathrm{dfy}$ & $+\mathrm{dfr}, \mathrm{dfy}$ & $+\mathrm{dfr}, \mathrm{dfy}$ & $+\mathrm{dfr}, \mathrm{dfy}$ \\
$\begin{array}{l}\text { Recursive } \\
\text { estimation }\end{array}$ & $8.82^{*}$ & $+\mathrm{dfy}$ & $+\mathrm{dfy}$ & $+\mathrm{dfy}$ \\
\hline \hline
\end{tabular}

\begin{tabular}{|c|c|c|c|c|}
\hline Utils2 & $\begin{array}{l}\text { 1947m1-2012 } \\
\text { m12 }\end{array}$ & $\begin{array}{l}\text { 1972m1-2012 } \\
\text { m12 }\end{array}$ & $\begin{array}{l}\text { 1982m1-2012 } \\
\text { m12 }\end{array}$ & $\begin{array}{l}\text { 1972m1-2002 } \\
\text { m12 }\end{array}$ \\
\hline $\begin{array}{l}\text { Benchmark } \\
\text { model }\end{array}$ & $\operatorname{AR}(6)$ & $\operatorname{AR}(6)$ & $\operatorname{AR}(6)$ & $\operatorname{AR}(6)$ \\
\hline New model & + dfy & + dfy & + dfy & + dfy \\
\hline $\begin{array}{l}\text { Rolling } \\
\text { estimation }\end{array}$ & -1.02 & -4.49 & -5.66 & -0.80 \\
\hline \multirow[t]{2}{*}{$\begin{array}{l}\text { Recursive } \\
\text { estimation }\end{array}$} & $2.09 *$ & -0.91 & 1.70 & -1.51 \\
\hline & $\begin{array}{l}\text { 1947m1-2012 } \\
\text { m12 }\end{array}$ & $\begin{array}{l}\text { 1972m1-2012 } \\
\text { m12 }\end{array}$ & $\begin{array}{l}\text { 1982m1-2012 } \\
\text { m12 }\end{array}$ & $\begin{array}{l}\text { 1972m1-2002 } \\
\text { m12 }\end{array}$ \\
\hline $\begin{array}{l}\text { Benchmark } \\
\text { model }\end{array}$ & $+\mathrm{dfr}, \mathrm{dfy}$ & $+\mathrm{dfr}, \mathrm{dfy}$ & $+\mathrm{dfr}, \mathrm{dfy}$ & $+\mathrm{dfr}, \mathrm{dfy}$ \\
\hline New model & + dfy & + dfy & + dfy & + dfy \\
\hline $\begin{array}{l}\text { Rolling } \\
\text { estimation }\end{array}$ & 6.96 & 10.40 & 13.90 & -0.68 \\
\hline $\begin{array}{l}\text { Recursive } \\
\text { estimation }\end{array}$ & 1.25 & 0.84 & 0.48 & $0.43 *$ \\
\hline
\end{tabular}


Table 8b: Out-of-sample Test Results for Predictive Accuracy (continued)

\begin{tabular}{|c|c|c|c|c|}
\hline Medeq3 & $\begin{array}{l}1947 \mathrm{~m} 1-2012 \\
\text { m12 }\end{array}$ & $\begin{array}{l}1972 m 1-2012 \\
\text { m12 }\end{array}$ & $\begin{array}{l}1982 \mathrm{~m} 1-2012 \\
\text { m12 }\end{array}$ & $\begin{array}{l}\text { 1972m1-2002 } \\
\text { m12 }\end{array}$ \\
\hline $\begin{array}{l}\text { Benchmark } \\
\text { model }\end{array}$ & $\operatorname{AR}(6)$ & $\operatorname{AR}(6)$ & $\operatorname{AR}(6)$ & $\operatorname{AR}(6)$ \\
\hline New model & +dfy, infl, dfr & $+\mathrm{dfy}$, infl, dfr & $+\mathrm{dfy}$, infl, dfr & $+\mathrm{dfy}$, infl, dfr \\
\hline $\begin{array}{l}\text { Rolling } \\
\text { estimation }\end{array}$ & $18.60 * * *$ & 4.95 & 7.48 & -1.67 \\
\hline \multirow[t]{2}{*}{$\begin{array}{l}\text { Recursive } \\
\text { estimation }\end{array}$} & $32.70 * * *$ & 5.73 & $24.00 * *$ & -12.50 \\
\hline & $\begin{array}{l}\text { 1947m1-2012 } \\
\text { m12 }\end{array}$ & $\begin{array}{l}\text { 1972m1-2012 } \\
\text { m12 }\end{array}$ & $\begin{array}{l}\text { 1982m1-2012 } \\
\text { m12 }\end{array}$ & $\begin{array}{l}\text { 1972m1-2002 } \\
\text { m12 }\end{array}$ \\
\hline $\begin{array}{l}\text { Benchmark } \\
\text { model }\end{array}$ & $+\mathrm{dfr}$, dfy & $+\mathrm{dfr}$, dfy & + dfr, dfy & $+\mathrm{dfr}$, dfy \\
\hline New model & $+\mathrm{dfy}$, infl, dfr & $+\mathrm{dfy}, \mathrm{infl}, \mathrm{dfr}$ & $+\mathrm{dfy}$, infl, dfr & $+\mathrm{dfy}$, infl, dfr \\
\hline $\begin{array}{l}\text { Rolling } \\
\text { estimation }\end{array}$ & 1.20 & 0.10 & 1.27 & -1.89 \\
\hline $\begin{array}{l}\text { Recursive } \\
\text { estimation }\end{array}$ & $5.79 * *$ & 5.12 & $6.59 *$ & -1.84 \\
\hline
\end{tabular}

\begin{tabular}{|c|c|c|c|c|}
\hline Cnstr3 & $\begin{array}{l}\text { 1947m1-2012 } \\
\text { m12 }\end{array}$ & $\begin{array}{l}\text { 1972m1-2012 } \\
\text { m12 }\end{array}$ & $\begin{array}{l}\text { 1982m1-2012 } \\
\text { m12 }\end{array}$ & $\begin{array}{l}\text { 1972m1-2002 } \\
\text { m12 }\end{array}$ \\
\hline $\begin{array}{l}\text { Benchmark } \\
\text { model }\end{array}$ & $\operatorname{AR}(6)$ & $\operatorname{AR}(6)$ & $\operatorname{AR}(6)$ & $\operatorname{AR}(6)$ \\
\hline New model & $\begin{array}{l}\text { +dfr, dfy, } \\
\text { ipgvol, infl }\end{array}$ & $\begin{array}{l}+ \text { dfr, dfy, } \\
\text { ipgvol, infl }\end{array}$ & $\begin{array}{l}+ \text { dfr, dfy, } \\
\text { ipgvol, infl }\end{array}$ & $\begin{array}{l}+ \text { dfr, dfy, } \\
\text { ipgvol, infl }\end{array}$ \\
\hline $\begin{array}{l}\text { Rolling } \\
\text { estimation }\end{array}$ & 12.60 & 15.50 & 21.00 & 3.49 \\
\hline \multirow[t]{2}{*}{$\begin{array}{l}\text { Recursive } \\
\text { estimation }\end{array}$} & $9.02 * *$ & 7.38 & $15.70 * *$ & -3.59 \\
\hline & $\begin{array}{l}\text { 1947m1-2012 } \\
\text { m12 }\end{array}$ & $\begin{array}{l}\text { 1972m1-2012 } \\
\text { m12 }\end{array}$ & $\begin{array}{l}\text { 1982m1-2012 } \\
\text { m12 }\end{array}$ & $\begin{array}{l}1972 \mathrm{~m} 1-2002 \\
\text { m12 }\end{array}$ \\
\hline $\begin{array}{l}\text { Benchmark } \\
\text { model }\end{array}$ & $+\mathrm{dfr}, \mathrm{dfy}$ & $+\mathrm{dfr}, \mathrm{dfy}$ & + dfr, dfy & $+\mathrm{dfr}, \mathrm{dfy}$ \\
\hline New model & $\begin{array}{l}\text { +dfr, dfy, } \\
\text { ipgvol, infl }\end{array}$ & $\begin{array}{l}+ \text { dfr, dfy, } \\
\text { ipgvol, infl }\end{array}$ & $\begin{array}{l}\text { +dfr, dfy, } \\
\text { ipgvol, infl }\end{array}$ & $\begin{array}{l}+ \text { dfr, dfy, } \\
\text { ipgvol, infl }\end{array}$ \\
\hline $\begin{array}{l}\text { Rolling } \\
\text { estimation }\end{array}$ & 3.93 & 6.18 & 7.38 & 2.62 \\
\hline $\begin{array}{l}\text { Recursive } \\
\text { estimation }\end{array}$ & 2.65 & $5.34 *$ & $6.64 *$ & -0.59 \\
\hline
\end{tabular}


Table 8c: Out-of-sample Test Results for Predictive Accuracy (continued)

\begin{tabular}{|c|c|c|c|c|}
\hline Hardw3 & $\begin{array}{l}\text { 1947m1-2012 } \\
\text { m12 }\end{array}$ & $\begin{array}{l}\text { 1972m1-2012 } \\
\text { m12 }\end{array}$ & $\begin{array}{l}\text { 1982m1-2012 } \\
\text { m12 }\end{array}$ & $\begin{array}{l}\text { 1972m1-2002 } \\
\text { m12 }\end{array}$ \\
\hline $\begin{array}{l}\text { Benchmark } \\
\text { model }\end{array}$ & $\operatorname{AR}(6)$ & $\operatorname{AR}(6)$ & $\operatorname{AR}(6)$ & $\operatorname{AR}(6)$ \\
\hline New model & $+\mathrm{dfr}, \mathrm{dfy}, \mathrm{tms}$ & $+\mathrm{dfr}, \mathrm{dfy}, \mathrm{tms}$ & $+\mathrm{dfr}, \mathrm{dfy}, \mathrm{tms}$ & $+\mathrm{dfr}, \mathrm{dfy}, \mathrm{tms}$ \\
\hline $\begin{array}{l}\text { Rolling } \\
\text { estimation }\end{array}$ & 2.59 & 2.89 & 0.65 & $6.35 *$ \\
\hline \multirow[t]{2}{*}{$\begin{array}{l}\text { Recursive } \\
\text { estimation }\end{array}$} & $6.19 * *$ & 2.97 & 0.18 & 4.28 \\
\hline & $\begin{array}{l}\text { 1947m1-2012 } \\
\text { m12 }\end{array}$ & $\begin{array}{l}\text { 1972m1-2012 } \\
\text { m12 }\end{array}$ & $\begin{array}{l}\text { 1982m1-2012 } \\
\text { m12 }\end{array}$ & $\begin{array}{l}\text { 1972m1-2002 } \\
\text { m12 }\end{array}$ \\
\hline $\begin{array}{l}\text { Benchmark } \\
\text { model }\end{array}$ & $+\mathrm{dfr}, \mathrm{dfy}$ & $+\mathrm{dfr}, \mathrm{dfy}$ & $+\mathrm{dfr}$, dfy & $+\mathrm{dfr}, \mathrm{dfy}$ \\
\hline New model & $+\mathrm{dfr}, \mathrm{dfy}, \mathrm{tms}$ & $+\mathrm{dfr}, \mathrm{dfy}, \mathrm{tms}$ & $+\mathrm{dfr}, \mathrm{dfy}, \mathrm{tms}$ & $+\mathrm{dfr}, \mathrm{dfy}, \mathrm{tms}$ \\
\hline $\begin{array}{l}\text { Rolling } \\
\text { estimation }\end{array}$ & $4.26 *$ & $6.87 *$ & 4.75 & $6.44 *$ \\
\hline $\begin{array}{l}\text { Recursive } \\
\text { estimation }\end{array}$ & $3.85^{*}$ & 3.64 & 0.00 & 4.78 \\
\hline
\end{tabular}

\begin{tabular}{|c|c|c|c|c|}
\hline Fin3 & $\begin{array}{l}\text { 1947m1-2012 } \\
\text { m12 }\end{array}$ & $\begin{array}{l}\text { 1972m1-2012 } \\
\text { m12 }\end{array}$ & $\begin{array}{l}\text { 1982m1-2012 } \\
\text { m12 }\end{array}$ & $\begin{array}{l}\text { 1972m1-2002 } \\
\text { m12 }\end{array}$ \\
\hline $\begin{array}{l}\text { Benchmark } \\
\text { model }\end{array}$ & $\operatorname{AR}(6)$ & $\operatorname{AR}(6)$ & $\operatorname{AR}(6)$ & $\operatorname{AR}(6)$ \\
\hline New model & $\begin{array}{l}\text { +dfr, dfy, ipg, } \\
\text { infl }\end{array}$ & $\begin{array}{l}+ \text { dfr, dfy, ipg, } \\
\text { infl }\end{array}$ & $\begin{array}{l}\text { +dfr, dfy, ipg, } \\
\text { infl }\end{array}$ & $\begin{array}{l}\text { +dfr, dfy, ipg, } \\
\text { infl }\end{array}$ \\
\hline \multirow{3}{*}{$\begin{array}{l}\text { Rolling } \\
\text { estimation } \\
\text { Recursive } \\
\text { estimation }\end{array}$} & $18.1 * *$ & $22.9 *$ & $30.4^{*}$ & $2.84 * *$ \\
\hline & $7.94 * * *$ & 4.86 & $11.8 * *$ & -4.42 \\
\hline & $\begin{array}{l}\text { 1947m1-2012 } \\
\text { m12 }\end{array}$ & $\begin{array}{l}\text { 1972m1-2012 } \\
\text { m12 }\end{array}$ & $\begin{array}{l}\text { 1982m1-2012 } \\
\text { m12 }\end{array}$ & $\begin{array}{l}1972 \mathrm{~m} 1-2002 \\
\text { m12 }\end{array}$ \\
\hline $\begin{array}{l}\text { Benchmark } \\
\text { model }\end{array}$ & + dfr, dfy & $+\mathrm{dfr}$, dfy & + dfr, dfy & $+\mathrm{dfr}, \mathrm{dfy}$ \\
\hline New model & $\begin{array}{l}\text { +dfr, dfy, ipg, } \\
\text { infl }\end{array}$ & $\begin{array}{l}\text { +dfr, dfy, ipg, } \\
\text { infl }\end{array}$ & $\begin{array}{l}\text { +dfr, dfy, ipg, } \\
\text { infl }\end{array}$ & $\begin{array}{l}\text { +dfr, dfy, ipg, } \\
\text { infl }\end{array}$ \\
\hline $\begin{array}{l}\text { Rolling } \\
\text { estimation }\end{array}$ & 0.73 & 0.44 & 0.42 & -0.08 \\
\hline $\begin{array}{l}\text { Recursive } \\
\text { estimation }\end{array}$ & $3.08 * *$ & $4.72 *$ & $5.11 *$ & $2.36 * *$ \\
\hline
\end{tabular}


Table 8d: Out-of-sample Test Results for Predictive Accuracy (continued)

\begin{tabular}{|c|c|c|c|c|}
\hline Rlest3 & $\begin{array}{l}1947 \mathrm{~m} 1-2012 \\
\text { m12 }\end{array}$ & $\begin{array}{l}1972 m 1-2012 \\
\text { m12 }\end{array}$ & $\begin{array}{l}1982 \mathrm{~m} 1-2012 \\
\text { m12 }\end{array}$ & $\begin{array}{l}1972 \mathrm{~m} 1-2002 \\
\text { m12 }\end{array}$ \\
\hline $\begin{array}{l}\text { Benchmark } \\
\text { model }\end{array}$ & $\operatorname{AR}(6)$ & $\operatorname{AR}(6)$ & $\operatorname{AR}(6)$ & $\operatorname{AR}(6)$ \\
\hline New model & $+\mathrm{dfr}, \mathrm{dfy}$, infl & $+\mathrm{dfr}, \mathrm{dfy}$, infl & $+\mathrm{dfr}, \mathrm{dfy}$, infl & $+\mathrm{dfr}, \mathrm{dfy}$, infl \\
\hline $\begin{array}{l}\text { Rolling } \\
\text { estimation }\end{array}$ & $82.60 * * *$ & $39.60 * * *$ & $52.20 * * *$ & $16.20 * * *$ \\
\hline \multirow[t]{2}{*}{$\begin{array}{l}\text { Recursive } \\
\text { estimation }\end{array}$} & $139.00 * * *$ & $128.00 * * *$ & $126.00 * * *$ & $86.80 * * *$ \\
\hline & $\begin{array}{l}\text { 1947m1-2012 } \\
\text { m12 }\end{array}$ & $\begin{array}{l}\text { 1972m1-2012 } \\
\text { m12 }\end{array}$ & $\begin{array}{l}\text { 1982m1-2012 } \\
\text { m12 }\end{array}$ & $\begin{array}{l}1972 \mathrm{~m} 1-2002 \\
\mathrm{~m} 12\end{array}$ \\
\hline $\begin{array}{l}\text { Benchmark } \\
\text { model }\end{array}$ & $+\mathrm{dfr}$, dfy & $+\mathrm{dfr}$, dfy & + dfr, dfy & + dfr, dfy \\
\hline New model & $+\mathrm{dfr}, \mathrm{dfy}$, infl & $+\mathrm{dfr}, \mathrm{dfy}$, infl & $+\mathrm{dfr}, \mathrm{dfy}$, infl & $+\mathrm{dfr}, \mathrm{dfy}$, infl \\
\hline $\begin{array}{l}\text { Rolling } \\
\text { estimation }\end{array}$ & 2.94 & 4.67 & 5.88 & -0.46 \\
\hline $\begin{array}{l}\text { Recursive } \\
\text { estimation }\end{array}$ & $8.39 * * *$ & $12.30 * * *$ & $10.80 * *$ & $6.94 * * *$ \\
\hline
\end{tabular}

Tables 8a to 8d report the out-of-sample results for selected industries, using rolling and recursive estimations. The format of the benchmark models and new forecasting model, as well as the Clark and West (2007) test statistics (multiplied by one million) and their significance, are presented according to industry. The upper panel of each table shows the Clark and West (2007) test results for the comparison between the AR (6) benchmark model and the new forecasting model. The lower panel presents the test results for comparison between the benchmark models (with default return and default yield) and the new models. $* * *, * *$ and $*$ represent statistical significance at the $1 \%, 5 \%$ and $10 \%$ level respectively. 